\title{
HUBUNGAN ANTARA PERSEPSI SANKSI PERPAJAKAN DENGAN KEPATUHAN PERPAJAKAN WAJIB PAJAK PBB DI KELURAHAN DURI PULO
}

\author{
Dwi Asri Julianita \\ Ati Sumiati
}

Universitas Negeri Jakarta

\begin{abstract}
This research was aimed to obtain valid and reliable data about The Relationship Between The Perception of the Tax Penalty and Tax Compliance on Taxpayer Land and Building Tax at Duri Pulo Villages Jakarta. This research was conducted by survey method with correlational approach. This research was conducted on February to December 2014. The population in this research were all taxpayer. Affordable population in this research were taxpayer land and building tax, amount to 71 persons. Total of samples used were 58 persons research. Sampling technique used simple random sampling. The result from this study partial and simultaneous testing of consciousness there significantly influence to tax penalty and Tax Compliance on Taxpayer Land and Building Tax.
\end{abstract}

Keywords: Tax Penalty, Tax Compliance

\section{PENDAHULUAN}

\section{Latar Belakang}

Rendahnya tingkat kepatuhan mempengaruhi rendahnya penerimaan pajak. Ketidakpatuhan wajib pajak dalam melaksanakan perpajakkan disengaja atau tidak disengaja sejak lama menjadi sorotan.

Dalam kegiatan sehari-hari manfaat pajak sangat terasa. Namun, banyak masyarakat yang tidak menyadari manfaat tersebut yang mengakibatkan mereka enggan membayar pajak atau melaksanakan kewajiban pajaknya. Salah satu manfaat yang dirasakan masyarakat dalam kehidupan sehari-hari adalah subsidi BBM.

Ketidakpatuhan dapat dicermati dari faktor yang membuat masyarakat mematuhi atau tidak mematuhi suatu kewajiban pajak. Faktor-faktor yang mempengaruhi kepatuhan masyarakat dalam membayar pajak di lihat dari fenomena yang ada sekarang ini.

Dalam suatu kasus, rendahnya pengawasan dan sanksi atau denda yang dikenakan terhadap wajib pajak yang tidak patuh juga bisa menjadi salah-satu faktor yang perlu diperhatikan. Ada salah satu cara yang dapat dilakukan oleh Direktorat Jendral Pajak untuk mengubah cara 
pandang tentang pajak yang bukan lagi suatu kewajiban tetapi hak dan tentu saja akan secara signifikan mendongkrak tingkat kepatuhan wajib pajak yaitu dengan cara membatasi masa berlaku NPWP bagi wajib pajak baik perorangan atau badan (Direktorat Jendral Pajak, 1 Maret 2014).

Selanjutnya menurut Kepala Inspektorat Daerah Klaten Eko Medisukasto, ada sebanyak 178 pelanggaran di wilayah ini yang berpotensi merugikan negara dari 80 objek pemeriksaan terehdap perusahaan milik PemKab Klaten maupun satuan kerja perangkat daerah (SKPD). Temuan yang berpotensi merugikan negara terjadi di Obrik Badan Kredit Kecamatan (BKK) Jatinom sebelum dimarger dan pelanggaran terhadap kewajiban setor kepada negara terjadi di tubuh sejumlah pemerintah desa yang tidak menyerahkan pajak bumi dan bangunan (PBB). Penyebab pelanggaran itu sebagian besar dikarenakan kelemahan terhadap pembinaan, pencatatan, maupun kelemahan pengawaan (Direktorat jendral Pajak, 24 April 2014).

Menurut Herry Susanto, Selain banyaknya pengusaha nasional yang mangkir dari kewajiban membayar pajak, kesadaran masyarakat Indonesia untuk membayar pajak juga masih minim. Dari 238 juta jumlah penduduk Indonesia, hanya 7 juta saja yang taat pajak. Namun tingkat kesadaran masyarakat membayar pajak masih belum mencapai tingkat yang diharapkan karena masyarakat masih sinis dan kurang percaya terhadap keberadaan pajak yang dianggap sama seperti upeti, memberatkan, pembayarannya sering mengalami kesulitan, dll. Direktur Jendral Pajak memaparkan masih jutaan yang belum bayar pajak berdasarkan data SPT pajak tahun 2010, orang pribadi hanya 8,5 juta dari total jumlah penduduk Indonesia sekitar 240 juta jiwa (Direktorat Jendral Pajak, 24 Februari 2014).

Menurut Surya Manurung dalam artikel Kompleksitas Kepatuhan Pajak, persentase tingkat kepatuhan wajb pajak pada tahun 2012 masih tergolong rendah. Menurut Menteri Keuangan bahwa orang pribadi yang seharusnya membayar pajak sebanyak 60 juta orang, yang mendaftarkan dirinya hanya 20 juta orang dan membayar pajaknya hanya 8,8 juta orang dengan rasio SPT 14,7 persen. 
Sementara badan usaha yang terdaftar sebanyak 5 juta, yang mau mendaftarkan dirinya sebagai wajib pajak hanya 1,9 juta dan yang membayar pajak/melapor Surat Pemberitahuan (SPT) Pajak Penghasilannya hanya 520 ribu badan usaha dengan rasio SPT sekitar 10,4 persen. Beberapa faktor yang menyebabkan rendahnya kepatuhan wajib pajak antara lain ketidakpuasan masyarakat terhadap pelayanan publik, pembangunan infrastruktur yang tidak merata, dan banyaknya kasus korupsi yang dilakukan pejabat tinggi (Direktorat Jendral Pajak, 24 Februari 2014).

Kasus lain menurut Ahmad Nur Supit menilai bahwa SDM untuk memungut pajak karena inisitif membayar pajak langsung dari masyarakat belum dapat diandalkan. Persoalan utamanya tenaga kerja. Tenaga kerja untuk memungut pajak karena system self assessment itu belum siap digunakan. Ada 50 juta WP yang baru terpungut 2 juta dan sisanya tidak bias begitu saja dipungut karena tenaga kerja yang sedikit (Inilah.com, 24 April 2014).

Oleh karena itu, berdasarkan pemaparan yang telah dikemukakan di atas, penelitian dengan judul, Hubungan antara Persepsi Sanksi Perpajakan dengan Kepatuhan Perpajakan menjadi hal yang menarik untuk diteliti secara lebih mendalam.

\section{Perumusan Masalah}

Berdasarkan pemaparan yang telah dilakukan di atas, maka perumusan masalah dalam penelitian adalah:

Apakah terdapat hubungan antara persepsi sanksi perpajakan dengan kepatuhan perpajakan?

\section{KAJIAN TEORETIK}

\section{Kepatuhan perpajakan}

Salah satu faktor tingginya penerimaan pajak adalah kepatuhan masyarakat dalam membayar pajak. Kepatuhan masyarakat dalam membayar pajak dikenal dalam istilah perpajakan adalah kepatuhan perpajakan yang merupakan situasi di mana wajib pajak melakukan kewajibannya sebagai wajib pajak.

\section{Safri Nurmatu (2005:148)} mendefinisikan kepatuhan perpajakan didefinisikan sebagai suatu keadaan dimana wajib pajak memenuhi semua kewajiban perpajakan dan melaksanakan hak perpajakan. 
Menurut Adrian Sutedi (2011:227) pengertian kepatuhan perpajakan adalah suatu keadaan dimana wajib pajak memenuhi semua kewajiban perpajakan dan melakukan hak perpajakan. Menurut Dwikora Harjo (2013:67) mendefinisikan kepatuhan perpajakan adalah suatu keadaan dimana WP memenuhi semua kewajiban perpajakan dan melaksanakan hak perpajakannya.

Menurut Kamus Umum Bahasa Indonesia dalam buku Siti Kurnia Rahayu (2010:138) tentang kepatuhan perpajakan adalah istilah kepatuhan berarti tunduk atau patuh pada ajaran atau aturan. Dalam perpajakan memberi pengertian bahwa kepatuhan perpajakan merupakan ketaatan, tunduk dan patuh serta melaksanakan ketentuan perpajakan.

Kepatuhan wajib pajak dikemukakan oleh Norman D. Nowak (Sony Devano, 2006) sebagai suatu iklim kepatuhan dan kesadaran pemenuhan kewajiban perpajakan, tercermin dalam situasi di mana:

a. Wajib pajak paham atau berusaha untuk memahami semua ketentuan peraturan perundang-undangan perpajakan. b. Mengisi formulir pajak dengan lengkap dan jelas.

c. Menghitung jumlah pajak yang terutang dengan benar.

d. Membayar pajak terutang tepat pada waktunya.

Menurut Safri Nurmantu (2005:148-149) ada dua macam kepatuhan perpajakan, yaitu kepatuhan formal dan kepatuhan material, yaitu kepatuhan formal adalah suatu keadaan di mana wajib pajak memenuhi kewajiban secara formal sesuai dengan ketentuan dalam undang-uandang perpajakan. Misalnya, ketentuan batas waktu dalam penyampaian SPT PPh tahunan tangal 31 Maret. Apabila melaporkan SPT sebelum batas waktu memasukan SPT tanggal 31 Maret, maka wajib pajak dianggap telah memenuhi kepatuhan formal. Sedangkan kepatuhan material adalah suatu keadaan di mana wajib pajak secara substantive atau hakekatnya memenuhi semua ketentuan material perpajakan, yakni susuai isi dan jiwa Undang-undang perpajakan. Wajib pajak yang memetuhi kepatuhan formal adalah wajib pajak yang mengisi SPT dengan jujur, lengkap dan benar sesuai dengan ketentuan. 
Kepatuhan material dapat meliputi kepatuhan formal.

Menurut Dwikora Harjo (2013:67) menjelaskan terdapat dua macam kepatuhan, yaitu kepatuhan formal dan kepatuhan material. Kepatuhan formal adalah suatu keadaan dimana WP memenuhi kewajiban perpajakan secara formal sesuai dengan ketentuan dalam perundang-undangan perpajakan. Contoh: menyampaikan SPT tepat waktu. Sedangkan kepatuhan material adalah suatu keadaan dimana wajib pajak secara substansi (pada hakekatnya) memenuhi semua ketentuan material perpajakan sesuai isi dan jiwa perundang-undangan perpajakan. Contoh: mengisis SPT dengan baik, benar (jujur), dan lengkap.

\section{Persepsi Sanksi Perpajakan}

\section{a. Pengertian Persepsi}

Persepsi masyarakat terhadap sanksi perpajakan dalam pembahasan ini akan dibahas menganai pengertian atau konsep dari persepsi itu sendiri.

Persepsi menurut Kreitner dan Kinickid dalam buku Wibowo (2013:59) adalah proses kognitif yang memungkinkan kita menginterpretasikan dan memahami sekitar kita. Persepsi merupakan proses kognitif yang dialami semua orang dalam bermasyarakat untuk memahami lingkungannya melalui panca indera yang dimiliki. Persepsi dapat dipahami melalui suatu penafsiran sesuatu hal terhadap situasi sekitar.

Sedangkan menurut McShane dan Von Glinow dalam buku Wibowo (2013:59), persepsi merupakan proses menerima informasi, membuat pengertian tentang dunia disekitar. Menurutnya hal tersebut memerlukan pertimbangan informasi mana yang perlu diperhatikan, bagaimana mengkategorikan informasi, dan bagaimana menginterpretasikannya dalam kerangka kerja pengetahuan kita yang telah ada. Jadi sebuah informasi akan menjadi sebuah keyakinan diri seseorang apabila informasi tersebut dibentuk sesuai dengan pengetahuan yang telah ada.

Pendapat lainnya menurut Robbins dalam buku Wibowo (2013:59), persepsi adalah suatu proses dimana individu mengorganisir dan menginterpretasikan tanggapan kesan mereka dengan maksud memberi makna pada lingkungan mereka. Tetapi apa yang kita rasakan 
dapat berbeda dari realitas objektif. Salah satu faktor yang mempengaruhi persepsi menurut Robbins ialah perilaku persepsi. Bila seorang individu memandang suatu objek dan mencoba menafsirkan apa yang dilihatnya, penafsiran itu sangat dipengaruhi oleh karakteristik pribadi dari perilaku persepsi individu itu.

Dapat disimpulkan bahwa persepsi merupakan suatu rangkaian bagaimana seseorang melihat dengan indra, memilih sesuai dengan karakteristik pribadi, dan merenungkan semua anggapan untuk menciptakan gambaran sesuai dengan pengetahuan yang telah ada.

\section{b. Pengertian Sanksi Perpajakan}

Pengenaan sanksi dalam suatu peraturan perundang-undangan adalah suatu alat pencegah pelanggaran yang telah ditetapkan oleh ketentuan tertentu. Dalam perpajakan, kesengajaan dan kelalaian wajib pajak akan memperoleh sanksi perpajakan. Sanksi perpajakan adalah alat penjamin akan dituritu/dipatuhi/ditaati sebuah ketentuan perundang-undangan perpajakan.

Menurut Mardiasmo dalam buku yang berjudul Perpajakan Edisi Revisi
(2013:59) mendefinisikan bahwa sanksi perpajakan merupakan jaminan bahwa ketentuan peraturan perundangundangan perpajakan (norma perpajakan akan dituruti/ditaati/dipatuhi.

Menurut Erly Suandy (2011:L1) mendefinisikan sanksi perpajakan merupakan jaminan ketentuan peraturan perundangan perpajakan (norma perpajakan) akan ditaati atau dipatuhi. Sedangkan menurut Hilarius Abut (2010:68) sanksi perpajakan merupakan alat pencegah (preventive) agar wajib pajak tidak melanggar undang-undang atau norma perpajakan.

Menurut Diana Sari (2013:272) mengatakan sanksi perpajakan merupakan jaminan bahwa ketentuan peraturan perundang-undangan perpajakan (norma perpajakan) akan dituruti atau ditaati atau dipatuhi. Atau dengan kata lain sanksi perpajakan merupakan alat pencegah (preventive) agar tidak melanggar norma perpajakan.

\section{Macam - Macam Sanksi Perpajakan}

Dalam undang-undang perpajakan dikenal dua macam sanksi 
perpajakan yang terdapat pada buku Mardiasmo ((2013:59), yaitu sanksi administrasi dan sanksi pidana:

a) Sanksi Administrasi

Sanksi Administrasi merupakan pembayaran kerugian kepada Negara, khususnya berupa bunga, denda, dan kenaikan.

b) Sanksi Pidana

Sanksi pidana merupakan suatu alat terakhir atau benteng hokum yang digunakan fiskus agar norma perpajakan dipatuhi.

\section{Denda Pidana}

Berbeda dengan sanksi berupa administrasi yang hanya diancam/dikenakan kepada wajib pajak yang melanggar katentuan peraturan perpajakan.

\section{METODE PENELITIAN}

Populasi dalam penelitian ini adalah seluruh wajib pajak PBB yang terdaftar pada Kantor Kelurahan Duri Pulo Jakarta Pusat. Populasi terjangkau menggunakan metode purposive sampling dengan jumlah wajib pajak sebanyak 71 orang yang tersebar dalam satu kelurahan dengan kriteria jumlah objek pajak yang berkisaran Rp5.000.000 s.d.
Rp9.000.000 dan subjek pajak yang bertempat tinggal sesuai dengan objek pajak.

Dalam pengambilan sampel penelitian menggunakan teknik sempel acak. Merut Suharsimi (2010:177) mendefinisikan teknik sempel acak adalah teknik pengambilan sempel secara acak yang menganggap semua subjek-subjek dalam populasi sama. Jumlah sempel yang dijadikan penelitian sampel adalah 58 menggunakan tabel Issac dan Michael dengan taraf kesalahan 5\%.

Metode yang digunakan dalam penelitian ini adalah metode survei dengan pendekatan korelasi. Menurut Sugiyono (2009:6) menjelaskan bahwa survei digunakan untuk mendapatkan data dari tempat tertentu yang alamiah (bukan buatan), tetapi peneliti melakukan perlakuan dalam pengumpulan data, misalnya dengan mengedarkan kuesioner, test, wawancara tersetruktur, dan sebagainya (perlakuan tidak seperti eksperimen).

Pendekatan korelasi dipilih karena dapat memperlihatkan hubungan antara kedua variabel yaitu persepsi sanksi perpajakan sebagai $\mathrm{X}$ dan kepatuhan perpajakan sebagai $\mathrm{Y}$. 
Populasi dalam penelitian ini adalah seluruh wajib pajak PBB di Kelurahan Duri Pulo. Adapun populasi terjangkaunya yaitu wajib pajak yang mempunyai nilai objek pajak yang tinggi sebesar 71. Kemudian berdasarkan tabel Isaac dan Michael dengan taraf kesalahan 5\%, maka jumlah sampel sebanyak 58 siswa.

Sebelum dilakukan pengujian hipotesis, terlebih dahulu dilakukan pengujian persyaratan analisis, meliputi Uji Normalitas dan Uji Linearitas Regresi.

Teknik yang digunakan untuk melakukan pengujian normalitas data

\begin{tabular}{|l|r|r|} 
Mean & 78,12 & 52,26 \\
\hline Std. Deviasi & 3,50 & 4,54 \\
\hline Varians & 12,28 & 20,62 \\
\hline
\end{tabular}

1. Uji Persyaratan Analisis

a. Uji Normalitas

Pengujian normalitas yang digunakan adalah Uji Liliefors. Hasil Uji Normalitas terdapat pada tabel 3 berikut:

Tabel 3. Rangkuman Hasil Uji Normalitas

\begin{tabular}{|c|c|c|c|c|}
\hline \multicolumn{5}{|c|}{ Normalitas } \\
\hline $\begin{array}{c}\text { Galat } \\
\text { Taksira } \\
\mathbf{n}\end{array}$ & $\mathbf{N}$ & $\mathbf{L}_{\text {hitung }}$ & $\begin{array}{c}\mathbf{L}_{\text {tabel }} \\
\alpha=\end{array}$ & Keterangan \\
$\mathbf{5 \%}$ & \\
\hline Regresi & & & $\mathbf{5 \%}$ & \\
\hline Y atas X & 58 & 0,0382 & 0,1163 & Normal \\
\hline
\end{tabular}

adalah Uji Liliefors. Data yang terkumpul kemudian dianalisis dengan regresi dan korelasi.

\section{HASIL DAN PEMBAHASAN}

Berikut adalah distribusi data hasil penelitian.

\section{Tabel 1. Deskripsi Data Responden}

\begin{tabular}{|l|r|r|}
\hline \multicolumn{1}{|c|}{ Deskripsi } & \multicolumn{1}{|c|}{ Jumlah } & Presentase \\
\hline Jenis kelamin: & & \\
\hline Laki-laki & 37 & $64 \%$ \\
\hline Perempuan & 21 & $36 \%$ \\
\hline Total & 58 & $100 \%$ \\
\hline
\end{tabular}

Tabel 2. Rangkuman Deskripsi Data

\begin{tabular}{|l|c|c|}
\hline $\begin{array}{c}\text { Nilai } \\
\text { Tendensi } \\
\text { Sentral }\end{array}$ & $\begin{array}{c}\text { Sanksi } \\
\text { Perpajakan } \\
\text { (X) }\end{array}$ & $\begin{array}{c}\text { Kepatuhan } \\
\text { Perpajaka } \\
\text { n (Y) }\end{array}$ \\
\hline $\mathrm{N}$ & 58 & 58 \\
\hline
\end{tabular}

\section{b. Uji Linearitas Regresi}

Bentuk persamaan regresi berbentuk linear. Hal ini dapat dibuktikan dengan hasil penghitungan. $F_{\text {hitung }}=1,14$; sedangkan $F_{\text {tabel }}=1,88$.

\section{c. Pengujian Hipotesis}

Hasil analisis data menginformasikan bahwa persamaan regresi pasangan variabel ini adalah $\hat{Y}$ $=65,39+0,24 \mathrm{X}$. Hasil pengujian signifikansi dan linearitas persamaan regresi disajikan pada tabel 4 .

Tabel 4. ANOVA Uji

Keberartian dan Kelinieran Regresi 


\begin{tabular}{|c|c|c|c|c|c|c|}
\hline \multicolumn{7}{|c|}{ ANOVA LINERDOAN BERARTT } \\
\hline Sumber Variasi & dk & $\mathbb{N}$ & KT & FHitung & FTabel & Keter \\
\hline Regresila) & 1 & 333964.84 & 353964.84 & & & \\
\hline Regresil|b|al & 1 & 68.69 & 68.69 & & & Hoharly \\
\hline Residu(S) & $n-2=(58-2=56)$ & 631.47 & 11.28 & 6.09 & 4.01 & Regres \\
\hline Tuna Cocok (TC) & $k \cdot 2=(20-2=-18)$ & 221,72 & 12.32 & & & Hotidak he \\
\hline Kekeliruan $(G)$ & $n \cdot k=[58-20=38]$ & 409.75 & 10.78 & 1.14 & 1.88 & Regres. \\
\hline
\end{tabular}

Berdasarkan tabel di atas, dapat dinyatakan bahwa persamaan regresi tersebut adalah signifikan dan linear. Selanjutnya, tingkat hubungan antarvariabel dihitung melalui korelasi Product Moment, kemudian koefisien determinasi. Hasil pengujian disajikan pada tabel 5 .

Tabel 5. Pengujian Signifikan Koefisien Korelasi

\begin{tabular}{|c|c|c|c|}
\hline Persamaan Regresi & Koefisien Korelasi & Koefisien Determinasi & thitung \\
\hline$\hat{Y}=65,39+0,24 X$ & 0,3155 & $9,95 \%$ & 2,488 \\
\hline
\end{tabular}

Berdasarkan hasil pengujian signifikansi seperti yang terlihat pada tabel di atas, diketahui bahwa koefisien korelasi antara pola sanksi perpajakan (X) dengan kepatuhan perpajakan (Y) termasuk pada kategori sedang. Selain itu, berdasarkan uji t yang telah dilakukan, diketahui pula bahwa terdapat hubungan yang positif antar kedua variabel. Dengan kata lain, semakin tinggi sanksi perpajakan, maka kepatuhan perpajakan akan semakin tinggi pula.

Koefisien determinasi sebesar 0,095 menunjukkan bahwa sebesar 9,95\% variabel yang terdapat pada motivasi berprestasi ditentukan oleh variabel pola asuh orang tua dengan persamaan regresi $\hat{Y}=65,39+0,24 X$.

\section{KESIMPULAN, IMPLIKASI, DAN SARAN}

\section{Kesimpulan}

Berdasarkan hasil analisis dan penghitungan, maka dapat disimpulkan bahwa sanksi perpajakan mempengaruhi kepatuhan perpajakan wajib pajak pada Kelurahan Duri Pulo Jakarta. Dengan demikian, dapat disimpulkan dalam penelitian ini bahwa semakin baik sanksi perpajakan maka akan semakin tinggi atau baik pula kepatuhan perpajakan yang dimiliki wajib pajak. Begitu pun sebaliknya, semakin buruk sanksi perpajakan maka akan semakin rendah kepatuhan perpajakan yang dimiliki wajib pajak.

Selain itu, berdasarkan hasil penelitian yang telah dilakukan dapat diketahui bahwa data kepatuhan perpajakan ditentukan oleh sanksi perpajakan dan sisanya dipengaruhi 
oleh faktor-faktor lain yang tidak terdapat dalam variabel yang diteliti oleh peneliti.

\section{Implikasi}

Implikasi dari hasil penelitian ini adalah sanksi administrasi saat terlambat membayar pajak merupakan sub indikator terbesar pada variabel sanksi perpajakan. Ini menunjukkan bahwa wajib pajak yang mendapat sanksi administrasi saat terlambat membayar pajak memiliki tingkat kepatuhan perpajakan yang lebih tinggi dalam hidup dibandingkan wajib pajak yang mendapat sanksi administrasi saat tidak membayar pajak.

Kepatuhan formal merupakan indikator terbesar dari variabel kepatuhan perpajakan. Ini menunjukkan bahwa wajib pajak yang memiliki kepatuhan perpajakan yang tinggi akan memilih untuk mengisi SPOP tahunan dengan tepat waktu.

Sementara itu, indikator terendah dari variabel sanksi perpajakan adalah sanksi administrasi saat tidak membayar pajak. Hal ini menunjukan bahwa wajib pajak cenderung tidak ingin membayar pajak tanpa sanksi administrasi.

Indikator terendah dari variabel kepatuhan material adalah kepatuhan perpajakan. Hal ini menunjukan apabila wajib pajak yang tidak dikenakan sanksi administrasi akan memiliki tingkat kepatuhan material yang rendah, wajib pajak akan bersikap tidak baik, benar (jujur), dan lengkap saat mengisi SPOP.

\section{Saran}

Berdasarkan kesimpulan dan implikasi yang dikemukakan di atas, saran-saran yang dapat diberikan peneliti adalah:

a. Kepada wajib pajak agar lebih memiliki kepatuhan perpajakan dengan mengisi SPOP dengan baik, benar (jujur), dan lengkap, bukan hanya kepatuhan dalam membayar tepat waktu.

b. Untuk penelitian selanjutnya, diharapkan mengembangkan penelitian ini dengan cakupan populasi yang lebih luas, indikator yang lebih luas, ataupun dengan menambah variabel lain yang juga menjadi faktor yang mempengaruhi kepatuhan perpajakan, seperti kesadaran membayar pajak. Selain itu, peneliti juga menyarankan untuk melakukan penelitian secara khusus pada salah satu jenis sanksi perpajakan sehingga dapat 
memperoleh hasil yang lebih

mendalam.

c. Kepada pemerintah untuk dapat lebih meningkatkan sanksi perpajakan sesuai dengan aturan serta memberikan pengetahuan sanksi perpajakan. Pemerintah sebaiknya memberikan tarif yang konsisten kepada masyarakat.

DAFTAR PUSTAKA

Abut, Hillarius. Perpajakan

Indonesia. Jakarta: Didit Media, 2010. 
Arianto, Aris. Separo Lebih Desa Di Wonogiri Nunggak PBB. 2014.

http://www.timlo.net/baca/5951 1/separo-lebih-desa-diwonogiri-nunggak-pbb/ (Diakses tanggal 24 April 2014).

Arikunto, Suharsimi. Prosedur Penelitian Suatu Pendekatan Praktik. Jakarat: Rineka Cipta, 2010.

Devano, Sony dan Siti Kurnia Rahayu. Perpajakan: Konsep, Teori, dan Isu. Jakarta: Kencana, 2006.

Eprilianto, Indrato. 178 Kasus Di Klaten Berpotensi Rugikan Negara. 2014. http://www.timlo.net/baca/1449 1/178-kasus-di-klaten-

berpotensi-rugikan-negara/ (Diakses tanggal 24 April 2014).

Fuadi, Arabella Oentari dan Yenni Mangoting. "Pengaruh Kualitas Pelayanan Petugas Pajak, Sanksi Perpajakan, dan Biaya Kepatuhan Pajak Terhadap Kepatuhan wajib Pajak UMKM" pada

Tax\&Accounting, VOL.1,NO.1, 2013.

Harjo, Dwikora. Perpajakan Indonesia. Jakarta: Mitra Wacana Media, 2013.

Harto, Budi Yuni. DPR Minta Pemerintah Naikan Setoran Pajak. 2014. http://ekonomi.inilah.com/read/ detail/2102401/dpr-mintapemerintah-naikkan-setoran-
pajak\#.U4TStnKSzGA

(Diakses tanggal 24 April 2014).

Manurung, Surya. Kompleksitas Kepatuhan Pajak. 2014. http://www.pajak.go.id/content/ article/kompleksitas-kepatuhanpajak (Diakses tanggal 24 Februari 2014).

Mardiasmo. Perpajakan Edisi Revisi. Yogyakarta: ANDI, 2013.

Rahayu, Siti Kurnia. Perpajakan Indonesia Konsep dan Aspek Formal. Yogyakarta: Graha Ilmu, 2010.

Rahman, Aidin Fathur. NPWP: valid date thru?. 2014. http://www.timlo.net/baca/5951 1/separo-lebih-desa-diwonogiri-nunggak-pbb/ Diakses tanggal 1 Maret 2014).

Robbins, Stephen P. Perilaku Organisasi. Jakarta: PT. Indeks

Kelompok Gramedia, 2003.

Sari, Diana. Konsep Dasar Perpajakan. Jakarta: Refika Aditama, 2013.

Suandy, Erly. Perencanaan

Perpajakan. Jakarta: Salemba

Empat, 2011.

Sugiyono. Metode Penelitian Kuantitatif dan R\&D. Bandung: Alfabeta, 2009.

Sugiyono. Statistik Untuk Penelitian. Bandung: Alfabeta, 2010.

Supangat, Andi. Statistik dalam Kajian Deskriptif Inferensi 
dan Nonparametik. Jakarta:

Kencana, 2007.

Susanto, Herry. Membangun

Kesadaran dan Kepedulian

Sukarela Wajin Pajak. 2014.

http://www.pajak.go.id/content/ membangun-kesadaran-dan-

kepedulian-sukarela-wajib-

pajak (Diakses tanggal 24

Februari 2014).

Utami, Renny Sri. "Pengaruh Sanksi Perpajakan terhadap Kepatuhan Wajib Pajak dan Implikasinya pada Penerimaan Pajak", pada e-journal Unikom.

Utami, Thia Dwi dan Kardinal. "Pengaruh Kesadaran Wajib Pajak dan Sanksi Perpajakan Terhadap Kepatuhan Wajib pajak Orang Pribadi Pada Kantor Kantor Pelayanan Pajak Pratama Palembang" pada jurnal STIE MDP

Wibowo. Prilaku Dalam Organisasi. Jakarta: Rajawali, 2013.

Zain, Mohammad. Manajemen Perpajakan Edisi 3. Jakarta: Salemba Empat, 2008. 
